\title{
Mihail Kogălniceanu’s Historical Inquiry into the Question of Roma Slavery in
}

Mid-Nineteenth-Century Romanian

\section{Principalities}

\section{Chiriac Bogdan}

chiriac_bogdan@hotmail.com

https://orcid.org/0000-0001-9110-9543

Chiriac Bogdan is an independent researcher from Iași, Romania, working in the field of modern and contemporary Romanian history. He completed his postgraduate studies at Central European University (Budapest), where he earned his MA in Nationalism Studies (2008) and his $\mathrm{PhD}$ in Comparative History (2017). He has been involved in several research projects focusing on Holocaust studies and the history of Roma in modern Romania.

\section{Critical}

Romani Studies 


\section{Abstract}

This article examines Ochire istorică asupra sclăviei (A brief historical survey of slavery), a mid-nineteenth-century pioneering study about the history of slavery, to ascertain the growing influence of anti-slavery ideas in the framing of the new Romantic historical discourse about Roma slavery in the Romanian principalities. The study, written by the leading Romanian historian, writer, journalist, and liberal statesman Mihail Kogălniceanu (1817-1891), was published in 1853 in a censored edition and has received only limited scholarly attention due to its incomplete form (the full version of the original article has yet to be published). The present paper intends to provide a critical reflection on the main features of Kogălniceanu's analysis of the institution of slavery in the Romanian principalities by exploring the author's multilayered interest in the question of Roma slavery, his command of primary sources, and the underlying historical interpretation and social doctrines that framed his investigation.

\section{Keywords}

- Anti-slavery

- Romani slaves (robi)

- Romantic historical discourse

- Moldova

- Wallachia 


\section{Introduction}

Mihail Kogălniceanu (1817-1891) is rightfully celebrated in Romanian culture as one of the most influential intellectuals and statesmen of his Romantic generation on account of his leading role in the construction of modern Romanian historiography as well as the national Romanian state. In a sense, he epitomizes the local version of the nineteenth-century Romantic nationalist archetype: a scholar and a patriot actively engaged in the process of national emancipation, while advocating for social and cultural reforms for "the benefit and enlightenment" of disenfranchised groups. But as it is often the case with celebrated personalities enshrined in national pantheons, the myth often has overshadowed the historical figure, casting a sympathetic light on Kogălniceanu's greatest works, while obscuring lesser-known aspects of his prolific career as a militant journalist and abolitionist.

The study of Kogălniceanu's scholarly and political writings on the situation of Romani slaves in the Romanian principalities has inevitably been influenced by the issue of "selectiveness." This Westerntrained historian and reform-minded nobleman, who put his literary talent and energy in the service of reforming Romanian society, wrote several pioneering studies about the local enslaved Roma that have not received equal attention in Romanian historiography. His lengthier studies, such as Esquisse sur l'histoire, les mours et la langue des Cigains... from 1837 and Desrobirea Țiganilor. Oborîrea pronomiilor și privilegiilor de nascere și de castă. Emanciparea țăranilor (The manumission of Gypsies. The abolition of birth rights and cast privileges. The emancipation of peasants) ${ }^{[1]}$ from 1891, are more often quoted than the score of shorter yet poignant anti-slavery articles he published in several Moldavian journals during the 1850s. These articles anticipated Kogălniceanu's similarly undervalued study about the institution of slavery entitled Ochire istorică asupra sclăviei (A brief historical survey of slavery), published in 1853 in a truncated version because the Moldavian censorship bureau decided to suppress the final section, which dealt explicitly with Roma slavery, probably due to its inflammatory abolitionist message. Despite being incomplete, this pioneering study deserves a more careful analysis because it provides new insight into the evolution of Kogălniceanu's views on slavery and his attempts to resolve the inherent tension between his professed commitment to scientific objectivity in the study of the origins and evolution of slavery, on the one hand, and his strong moral condemnation of the dehumanizing effects of this reviled institution, on the other. To what extent, one can ask, did positivist history and militant abolitionism inform Kogălniceanu’s perspective on slavery?

This article examines Kogălniceanu's Ochire istorică asupra sclăviei from a historiographical perspective in an effort to ascertain the reciprocal influence of Romanian historical scholarship and anti-slavery discourse in nineteenth-century debates concerning Romani slaves. Its intention is to offer not an empirical social and economic analysis of slavery in the Romanian principalities, but a critical reflection on the major features of Kogălniceanu's historical interpretation about this "peculiar institution," as they were presented in his study.

1 All translations from Romanian into English (book titles and excerpts) are the author's, unless otherwise noted. 
The focus will fall upon Kogălniceanu's multilayered interest in the issue of Roma slavery, his command of primary sources, and the underlying historical interpretation and overarching social doctrines that framed his investigation, which will be reconstructed based on his rich correspondence, early works, journal articles, and discourses he delivered in the Romanian Academy.

\section{Literature Review}

The connection between historical scholarship and abolitionist discourse in Kogălniceanu's writings has not yet been the subject of any detailed investigation in Romanian historiography (Venera Achim 2006, 467). That Kogălniceanu's writings concerning the situation of Romani slaves contain a core antislavery argument was explicitly acknowledged in almost every biographical study dedicated either to his intellectual formation and career as a historian (Zub 1974, 366) or his social studies fighting for structural reforms in the principalities (Ionescu 1979, 123). Alexandru Zub, the author of the most detailed study about Kogălniceanu's historical writings, stressed in his brief survey of Ochire istorică asupra sclăviei that the abolition of slavery in Moldova represented the ultimate political goal of this pioneering study of social history (1974, 366-71). Virgil I. Ionescu pursued a similar line of argumentation, albeit in a more pronounced Marxist vein, underlining the role of the study in laying the foundation for Kogălniceanu's social criticism of the "feudal order" in Moldova (1963, 164-5; 1979, 23-5). Despite their differences in approach and tone, both authors tend to attach greater value to the abolitionist message of the study rather than its historical scholarship, on account of its incomplete (censored) form. Similarly, the fact that the section about dependent peasants was better preserved than the one dealing with Romani slaves has prompted scholars to devote more attention to Kogălniceanu's analysis of the local Moldavian and Wallachian varieties of serfdom. Aurel Răduțiu's study, for instance, stressed the centrality of the critical analysis of serfdom in promoting Kogălniceanu's message about peasant emancipation as a means of correcting nineteenth-century social injustices and fostering "social regeneration" $(1973,67)$.

The nexus between historical positivism, national discourse, and social militancy in Kogălniceanu's works has also been discussed in several studies concerning the evolution of nineteenth-century Romanian historiography. Kogălniceanu was one of the founding figures of the Romantic history school, whose studies on Romanian history were defined by his professed adherence to the methods of historical positivism, as well as his nation-centered vision of the past that aimed to go beyond political history by encompassing all social classes (Cristian 1996, 154-70). This new type of Romantic discourse about the past contained an inherent tension between the imperative to seek historical objectivity (narrating history "as things really were," according to Leopold von Ranke's famous adage) and the predilection for a reform-oriented rhetoric, advocating for national awakening, social reforms, and cultural modernization (Boia 2011, 89-90). Kogălniceanu's early historical works, infused with a typical Romantic interpretation of "national culture," tested the limits of the concept of historical "objectivity," as they revealed that his interpretation of the past, despite claiming to be impartial, was not free of the "subjective" influence of national ideals or reform aspirations. He attempted to resolve this tension by arguing in favor of writing a militant history (historia militans) that aimed not only to objectively reconstruct the past, but also to educate the youth in the spirit of patriotism and serve as a moral compass in contemporary politics. In a sense, the quest for historical truth was not fundamentally irreconcilable with the cultivation of 
patriotism, argued Kogălniceanu, as long as the right balance between these two tendencies could be maintained (Zub 1974, 410).

This article moves in a different direction than the mainstream historical interpretation on Kogălniceanu's study by focusing specifically on the latter's analysis of slavery. Fully aware of the difficulties raised by the interpretation of this censured article, I argue that the lacunae in the original text can be partially filled, within conceivable limits, with information extracted from Kogălniceanu's other studies on the situation of Roma, published either prior to 1853 (his Esquisse sur l'histoire... from 1837) or afterwards (his antislavery articles published during the 1850s and his discourses delivered in the Romanian Academy).

\section{The Author}

Before turning to the actual content of this article, Kogălniceanu's background needs to be briefly discussed in order to shed some light upon his motivation for writing about slavery in the first place. Explaining these writings as a mere expression of Romantic curiosity and philanthropy would not suffice. Kogălniceanu did share with the other Romanian men of letters of his generation, collectively known as the Forty-Eighters, a certain degree of interest in Romani culture and a level of sympathy for their sufferings as slaves. In fact, he became convinced of the evils of slavery from first-hand experience, since he was born in Iași in 1817 to a noble family of boyars (with free peasant roots) that owned seven or eight Romani slave families on its country estate in Rîpile, in central Moldova (Kogălniceanu 1837, 24). Still, his interest in this population went beyond conventional views, and the emancipation of Roma from slavery eventually became, according to a journal article he published in November 1855, "his life-long conviction" (Kogălniceanu 1855, 101). To find out what aroused such a strong passion in this offspring of a noble and affluent Moldavian family, we must look to Kogălniceanu’s formative years. Since a detailed account of his upbringing in Iași, studies in Western Europe, and voyages abroad would go beyond the scope of this paper, this section will make use of Kogălniceanu's autobiographical writings and letters to review those episodes of his youth relevant to the present investigation.

Kogălniceanu recounted the strong impression that the pitiful sight of Romani slaves, dragging their chains on the streets of Iași, his hometown, made upon him in his youth $(1892,266)$. It seems likely that Enlightenment ideas nurtured in his young mind a growing discontent towards slavery and other local forms of social inequality. Like most of his peers coming from noble families, he completed his secondary education in two local boarding schools administered by French instituteurs or schoolmasters (Zub 1974, 44-62). It was in this environment that he first came into contact with the writings of several eighteenthcentury French philosophers that shaped his critical attitude towards the feudal privileges and social inequalities still in effect in early nineteenth-century Moldova.

This looming discontent turned into a full-fledged social critique during Kogălniceanu's studies in France and Prussia. Kogălniceanu always recalled the years of his university studies and long voyages in Western Europe as a formative period in his life, during which many of his political ideas, including his antislavery views, matured. Under the patronage of Mihail Sturdza, the new prince of Moldova (1834-1849), Kogălniceanu spent almost a year in the French city of Lunéville (1834-1835) in order to complete his 
secondary studies, and subsequently moved to Berlin (1835-1838) to become the first Romanian to gain admission to Friedrich Wilhelm University. Following his family's wish, he enrolled in the Faculty of Law, but decided to take a variety of courses in the field of humanities, in a heroic effort to satisfy his encyclopedic curiosity in this true citadel of learning (the "Athens of Germany," as he liked to refer to his alma mater in Berlin). He recalled the strong influence that the courses taught by distinguished professors such as Eduard Gans (natural law), Friedrich Karl (also spelled Carl) von Savigny (Roman law), and Leopold von Ranke (modern history) had upon his intellectual and professional development (Kogălniceanu 1892, 259). From each of them, Kogălniceanu assimilated a set of core notions that steadily would be integrated into his own philosophy: Gans' unshaken belief in humankind's capacity for progress and improvement (social meliorism), von Savigny's elegant concept of organic progress in accordance with national specificity and the spirit of the time (Zub 1974, 98-103), and, above all else, Ranke's magisterial interpretation of historical objectivity and rigorous method of source criticism (Lupaș 1937, 320).

Ranke's formative influence over Kogălniceanu's writings can be traced back as early as 1837, while the latter was still his student in Berlin. While being under the direct impression of Ranke's lectures on modern history, young Kogălniceanu formulated an ambitious plan to write a new history of the Romanian people in French (ibid., 320). Although this intention was never fully materialized, Kogălniceanu did manage to draft several preliminary sections that would eventually be published as stand-alone works. Such was the case of his study on Romanian Roma, published in 1837 under the title Esquisse sur l'histoire, les mours et la langue des Cigains... and presented as being part of a forthcoming treatise of the history of the Romanian principalities (Zub 1974, 329).

Two fateful encounters within the liberal political circles in Berlin turned Kogălniceanu's interest in the Romani population into a long-lasting scholarly and abolitionist pursuit. In 1836 he met with the Duke of Cumberland's son, George, the future King George V of Hanover (1819-1878), who displayed a strong passion for Oriental languages and asked Kogălniceanu for more information about Roma living in Moldova (Zub 1974, 300). He also encountered Alexander von Humboldt and struck up a friendship with this fascinating polymath, naturalist, explorer, and geographer, who also made inquiries about Roma living in Moldova. It was von Humboldt who encouraged Kogălniceanu to publish his Esquisse sur l'histoire, les mours et la langue des Cigains... in 1837 (Kogălniceanu 1892, 260). Traditionally, von Humbold's inquiries about Roma were explained in connection with his larger research interest in ethnography and linguistics (Ionescu 1963, 161; Zub 1974, 329-30). However, von Humboldt's questions, according to Kogălniceanu's account, touched upon not only on the distinctive traits of Roma living in Moldova, but also on their current situation $(1892,260)$. This detail, along with the clear abolitionist message contained in Kogălniceanu's study from 1837, suggests that the German polymath's inquiries might have also had philanthropic or even abolitionist overtones. This should hardly come as a surprise, given von Humboldt's sharp criticism of the situation of enslaved populations in the Spanish colonies and his insistence on the fundamental equality of all "racial groups" (Dassow Walls 2009, 173-209). Further research on Kogălniceanu's correspondence with von Humboldt might clarify whether the latter made direct reference to Roma in his strong criticism of slavery.

Kogălniceanu returned to Iași in 1838, eager to place his newly acquired knowledge and abilities in the service of reforming the archaic Moldavian institutions. His projects for liberal reform, however, soon foundered 
on sharp disagreement with local conservative boyars, while his initial cordial relations with Prince Sturdza became strained to the point that the latter ordered to have the outspoken young reformer imprisoned for six weeks in 1844 (Zub 2005, 48). After being released, Kogălniceanu decided to go into a self-imposed exile and join the ranks of the group of young Romanian liberals living in Paris. Although his autobiographical notes offer scant details about this period in his life, the year Kogălniceanu spent in the capital of France influenced his projects for reforming Moldavian society, including the institution of slavery. In 1846, he met with Paul Bataillard and other French scholars and men of letters advocating for the abolition of slavery, joined the ranks of Société Orientale de France, an Orientalist society in Paris, and expressed his intention to publish an article about Roma (Cartojan 1925, 11). Like his other militant articles, this one was probably intended to describe the situation of Romani slaves, as well as chastise the evils of slavery.

\section{The Historical Context}

Kogălniceanu's discourse on slavery, shaped deeply by his philanthropic values, Romantic curiosity, critical attitude towards the Moldavian ancien régime, and Western intellectual formation as a jurist and historian, assumed a distinctive militant tone in response to the historical context in which he developed it. A brief look at the contemporary cultural and political debates in the principalities concerning social reform and abolitionism will provide some context for examining why Kogălniceanu's article faced the rigours of censorship in 1853.

Slavery was a century-old institution, firmly entrenched in the social and economic structures of the Principality of Moldova during the nineteenth century (Viorel Achim 2004, 87). At the risk of oversimplifying a complex situation, it can be argued that the nearly 250,000 Romani slaves living in Moldova and Wallachia toiled on the estates of their masters (the Crown, the boyars, or the Orthodox monasteries) or plied their itinerant trades up and down commercial roads or on the outskirts of villages and towns, just as their ancestors had done over the past four centuries (Potra 1939, 66-86). Their situation began to show signs of change in the early nineteenth century, as the political structures of the ancien régime underwent changes due to the rapid developments in the international statute of the principalities (the formal establishment of the Russian protectorate in 1829, which increasingly eroded Ottoman suzerainty), and more gradual social and economic developments (the non-linear transition from a feudal-type order to "an early form" of capitalist economy) (Hitchins 2014, 62-5). These changes were determined by, and in turn determined, a series of changes in attitudes towards local Roma of certain reform-minded members of the ruling elites, who began to question the nature and utility of the institution of slavery and put forward various reform projects, motivated by Enlightenment ideas (Iordachi 2019, 142-6). As it did with several other aspects of modern Romanian culture, French militant literature served as an enduring source of inspiration in the development of the local anti-slavery discourse (Tomi 2009, 12-13). Since these changes are too complex to summarize in the pages of this article, I will use Kogălniceanu's personal involvement with several groups of liberal reformers from 1837 to 1856 as a case study to illustrate the development of abolitionist ideas and initiatives in Moldova.

During the first stage of "Romantic initiatives" (from the late 1830s to the mid-1840s), Kogălniceanu joined a group of young reformist boyars who used to gather in Răducanu Rosetti’s mansion in Iași to 
discuss possible solutions for modernizing the antiquated institutions and social structures in Moldova. The abolition of slavery, seen by most as the embodiment of all that was shameful and wrong with the ancien régime in their fatherland, was on top of the reform list (Kogălniceanu 1892, 265). Whereas some participants felt compelled to speak against slavery out of a certain consciousness of civic responsibility toward Roma and other groups "less fortunate in birth and circumstances." ${ }^{[2]}$ Kogălniceanu developed a sharp critique of "this peculiar institution" on humanitarian, social, and cultural grounds. He denounced it as unnatural, cruel, corrupting for both slaves and their masters, and detrimental to the country's national interests, as it was viewed in Western Europe as the epitome of "backwardness and oppression" in Moldova (ibid., 266).

Prince Mihail Sturdza, the ruler of Moldova, accepted some of the proposals put forward by this reformist group, as long as it suited his purpose of appeasing the growing restlessness among the young generation of boyars (Ciurea 2012, 56-7). It was probably under their influence that the prince decreed the partial abolition of slavery - that is, the emancipation of both Crown and monastery slaves - in January to February 1844. In order to show his support for such a salutary measure, Kogălniceanu wrote a laudatory article in the local review Foia științifică și literară (Scientific and literary review) on 6 February 1844 (Kogălniceanu 1974, 1: 552-4). It appears that the prince intended to emancipate privately owned slaves as well, but had to delay such a reform and distance himself from local reformist circles due to the opposition of certain conservative boyars (Kogălniceanu 1892, 267).

The tensions between liberal circles, conservative boyars, and authoritarian monarchs on the subject of reforms, including the complete abolition of slavery, reached a boiling point in the spring and summer of 1848, when the Forty-Eighters set in motion revolutionary movements in Moldova and Wallachia. During this short-lived stage of "revolutionary fervor" of 1848 to 1849, Kogălniceanu adopted a more "immediatist" stance on the abolition of privately owned slaves, in brochures such as Dorințele partidei naționale in Moldova (The demands of the National Party in Moldova) from August 1848. He rejected moderate reforms and demanded the total and immediate emancipation of those slaves owned by boyars "with compensations awarded to those who demand them" (Bodea 1982, 661). The implementation of such radical measures became possible only in Wallachia, where the revolutionaries were able to topple Prince Gheorghe Bibescu's regime and establish a provisional government (Venera Achim 2009, 2). In Moldova, Prince Sturdza's repressive measures, coupled with the swift Russian intervention, quickly crushed the revolutionary initiative and forced many Forty-Eighters, including Kogălniceanu, to flee into exile (Zub 2005, 56-7).

Kogălniceanu's return from exile in 1849 and the beginning of his political collaboration with the new prince, Grigore Alexandru Ghica (1849-1853, 1854-1856), marks the final stage of his involvement with abolitionist initiatives in Moldova. Prince Ghica initially pardoned several Forty-Eighters and included them in the new government, including Kogălniceanu, as proof of his genuine commitment to adopt a program of reforms (Boicu 1973, 35-7). Still, the indecisiveness, corruption, and political intrigue that

2 This expression was inspired by Article 4 of the First Section of the Civil Code of Wallachia of 1818 (Codul Caragea), which stated that "[persons are divided] based on their fortune [at birth] into free-born, slaves and freedmen." 
began to plague the new regime undermined Prince Ghica's credibility as a reformer and put a strain on his relationship with Kogălniceanu (Zub 1973, 619). Both statesmen shared an elitist perspective on the need to abolish the last vestiges of slavery through legal means but had divergent opinions about the timing and pace of the reforms. Pressured by conservative political circles, Prince Ghica was biding his time until he could find expedient means with which to achieve his goals without directly infringing upon the boyars' legal rights to own Romani slaves. Kogălniceanu's renewed calls in 1853 for the immediate abolition of slavery, in the context of the outbreak of the Crimean War and the Russian military occupation of Moldova, were probably seen as inopportune by Prince Ghica (Zub 1974, 337). It can be argued that the local censorship bureau decided to suppress the last section of Kogălniceanu's study on slavery due to its inflammatory abolitionist message, which was likely to irritate the slave-owning boyars and provide them with a pretext to complain to the Russian occupation forces that their property rights were under threat.

Kogălniceanu was eventually vindicated in November 1855, when Prince Ghica decided to emancipate privately owned Romani slaves in Moldova (Iordachi 2019, 159-60). Kogălniceanu was not only given wide latitude to voice his criticism against the institution of slavery and to praise Prince Ghica's wisdom for enacting such a liberal measure, but was also included in the committee tasked with drafting the emancipatory law (Kogălniceanu 1892, 611). For Kogălniceanu, this represented a fitting conclusion to his long struggle for the abolition of slavery and an eloquent testimony to his lifelong determination to bring about structural social change in the principalities.

\section{Source Interpretation}

In light of the discussion in the previous section, one may well ask what was so provocative about Kogălniceanu's study that it warranted the intervention of the Moldavian censorship bureau in 1853. After all, anti-slavery rhetoric had been used by Romanian Forty-Eighters for years to chastise the evils of slavery and to demand, with increased vehemence, more decisive measures. It was probably the judicious mixture of rhetorical skill and scholarly argument that set Kogălniceanu's study apart, given that in the author's previous writings on the topic he displayed an uncanny ability to use a wide array of moral, humanitarian, legal, and historical arguments to further the abolitionist cause.

The circumstances in which Kogălniceanu's study on slavery appeared in 1853 testify to the author's "versatility" when it came to evading the rigours of censorship in Moldova. Kogălniceanu wrote his study as a scholarly introduction to Harriet Beecher Stowe's anti-slavery novel, Uncle Tom's Cabin, originally published in the United States in 1852 and translated into Romanian (by proxy of Léon Pilatte's French translation) the following year by Theodor Codrescu as Coliba lui Moșu' Toma... (Beecher Stowe 1853). This novel enjoyed such a success in both principalities that another printing house in Iași commissioned a new edition in the same year and local admirers, such as Vasile A. Urechia, went as far as to write an Uncle Tom's Cabin pastiche (Ghenghea 2013, 92). The Romanian translation (printed in the Cyrillic transition alphabet) was published in a two-volume edition, and Kogălniceanu's 23-page introduction was inserted at the beginning of the first (Beecher Stowe 1853, ix-xxxii), only to end abruptly on page xxxii, right in the middle of a sentence, due to the ill-fated intervention of the censorship bureau. This was not Kogălniceanu's first collision with censorship, and it seems unlikely that he would have received 
permission to publish his study on slavery, in its original form, as a stand-alone article in 1853. It took almost two years and the acceptance of several uneasy compromises (the removal of all content related to modern times and the strict focus on antiquity) for the author to be able to publish a further abridged version of the initial study, under the new title Sclăvie, vecinătate şi boieresc (Slavery, serfdom, and corvée), in the review România literară (Literary Romania) (Simionescu 1955, 139).

Despite the compromises made, Kogălniceanu managed in the pages of his introductory study to develop a critical analysis of slavery as a social institution that retained a coherent structure. By social institution he meant a specific type of social structure or pattern of human activity that was subjected, at some point in time, to a process of legal codification. Aside from the opening paragraphs in which Kogălniceanu paid homage to Beecher Stowe's novel, his study assumed a life of its own as a well-researched historical study, removed from the influence of any rhetorical flourishes. As the title suggests ("ochire istorică" is the Romanian equivalent of the French expression “coup d'oil historique," meaning "a brief historical survey"), Kogălniceanu's intention was to go beyond providing a mere general introduction to the institution of slavery in the United States for Romanian readers. In fact, he planned to analyze the evolution of slavery as a legal and social institution across successive historical periods and various geographical areas in order to situate the Moldavian and Wallachian variety (robia) within a more general context. Thus, in the first part of the study (the first chapter, "Slavery in Antiquity," and the second chapter, "Serfdom"), he provided a general definition of slavery as a violation of natural law, by virtue of reducing people to the status of property. He then traced the preconditions (social stratification and wars of spoliation) that favored its appearance at the dawn of civilization, examined its archetypal manifestations during classical antiquity in Athens and Rome, then traced its transformation into "colonate" during late antiquity to finally arrive to the birth of medieval serfdom as an "ameliorated feudal variant of slavery" in Western Europe (Kogălniceanu 1976, 483-94). In the second part (the remaining section of the second chapter) he discussed the emergence and development of the Romanian variants of serfdom (rumânie in Wallachia, vecinie in Moldova, and iobăgie in Transylvania) until the eighteenth century. Just as Kogălniceanu was bringing into focus the period of social and institutional reforms in the Romanian principalities, the text ended abruptly at Prince Constantin Mavrocordat's measure to abolish serfdom in Moldova in 1749 by turning local serfs (vecini) into corvée peasants (ibid., 494-8). That possibility that Kogălniceanu, apart from some occasional remarks about Romani slaves, wrote a distinct chapter on slavery in the principalities (which was suppressed by censorship) can be clearly inferred from the following passage: "Slavery in ancient societies, serfdom in the middle ages, the slave trade and the condition of Black slaves in modern times - this will form the topic of our treatise, which will include a special chapter on Gypsies, the last remaining slaves in a Christian nation in Europe today" (ibid.,485).

Ochire istorică asupra sclăviei has been described as a pioneering study of social history that, despite its missing final section and somewhat tentative nature, displayed great originality (Simionescu 1955, 139; Răduțiu 1973, 67; Zub 1974, 366). Kogălniceanu was indeed breaking new ground with his approach to the topic of slavery in Romanian historiography, as he was arguably the first representative of the local Romantic school of history to examine this social phenomenon across its historical evolution and in relation to its regional specificity. Nicolae Bălcescu, the younger historian and fellow Forty-Eighter, had written a similar militant study of social history in 1846 entitled Despre starea soţială a muncitorilor plugari în Principatele Române in deosebite timpuri (On the social status of the ploughmen of the Romanian Principalities at various 
times) on the evolution of Romanian peasants (Bălcescu 1974, 151-62). Both historians employed a similar approach that displayed a certain familiarity with the emerging field of sociological investigation. Thus, they both delineated theoretical models of the social phenomena under review (slavery and serfdom) in a manner that exceeded the confines of legal-normative frameworks, and their respective analyses were not restricted to event-centered history, but also discussed the evolution of certain social groups and processes of social change (Răduțiu 1973, 68). Still, Kogălniceanu's study on slavery retained a distinctive historicist approach. According to him, the specific location and historical moment of the distinct forms of slavery provided not just an explanation for their variety, but actually conferred to them their specificity, according to the stages of historical development in which they had emerged:

Slavery has accompanied the history of human societies until this very day; it will certainly come to an end before humankind [does]; unfortunately, we have not yet come to witness the end of its existence. This history, as shameful as it is for our people, holds the greatest of interests; but such a study is too vast to be summarized into a brief survey; we will limit ourselves to the analysis of the key facts, meaning the role of slavery in ancient times, especially for the Greeks and the Romans. After the migration of people during the middle ages, slavery transformed itself in serfdom, an institution albeit less degrading, but still as barbaric because it tied men to the land (Kogălniceanu 1976, 484).

Kogălniceanu's predilection towards historical comparisons conferred his study an additional note of originality. Although not a proper comparative study, Ochire istorică asupra sclăviei made use of synchronic and diachronic comparisons between various ancient and modern, European and North American "slave systems." He drew succinct yet interesting parallels between what some modern-day historians would term a "slave-based system" from the Antebellum United States and the more patriarchal "slave-owning system" from the Romanian principalities, in an effort to identify both similarities across time and space, and connections that would help delineate a path of progress towards individual freedom. Here is how he described the system of slavery in the New World:

In modern times, an even more monstrous institution emerged and combined with the cruelty of old slavery, much to the shame of our civilization. The need to repopulate the recently discovered Americas in which the native populations had been decimated by the conquerors' sword, the religious preachers' zeal, and then the hardships of colonial agriculture in a very oppressive climate for Europeans, gave birth to the transatlantic slave trade, a new form of slavery founded upon the pretext of the inferiority of the African population compared to the white one (Kogălniceanu 1976,484-5).

Next, Kogălniceanu employed primary sources in a manner that can be described as both critical and innovative. He relied on information drawn from legal sources (codes of law and writs) and primary narrative sources (Ancient Greek and Roman treatises authored by Aristotle, Xenophon, Columella, and others, or res gestae or chronicles written by Moldavian boyars, such as Grigore Ureche), in his attempts to reconstruct the legal frameworks of the institutions of slavery. As for the study of medieval serfdom, Kogălniceanu used archival documents, collected from state or private repositories in Iași or Bucharest, to corroborate or complete the available narrative (primary) sources, such as Ureche's Letopisețul Țării 
Moldovei de când s-au descălecat țara (Chronicles of the Principality of Moldova from its foundation). He already had published some of these recently discovered documents in local historical reviews, including the chrysobull or the official resolution of the Moldavian Assembly of Estates that sanctioned the emancipation of Moldavian serfs in April 1749. He approached these sources from a critical perspective by distancing himself from the elitist perspective of nobiliary chronicles, expressing reservations towards dubious, embellished, or specious arguments included in Moldavian or Wallachian chronicles, and by seeking to bring to the forefront, as much as the available resources allowed him, "the common people," with their social organisation, customs, and institutions (Zub 1974, 370). In addition, he ingeniously filled in some of the lacunae in the narrative from primary sources pertaining to the history of Roma in the Romanian principalities with ethnographic and linguistic data, collected either by himself or other French and German researchers (Kogălniceanu 1837, 1-3).

After reviewing Kogălniceanu's multilayered approach and critical use of primary sources, it is now time to turn to his perspective on the institution of slavery. As most Romantic scholars writing in a turbulent political context, he found it difficult to adopt a neutral position towards such a reviled form of bondage that, despite sharp criticism, continued to flourish in the Romanian principalities at that time, and hence was not only controversial but still unresolved. The length to which his anti-slavery attitude influenced the direction and content of his scholarship remains open to debate. Kogălniceanu made no secret of his resolute anti-slavery stance, both in his political activity and his historical writings, arguing that scholars were also supposed to act as agents of social and cultural change, and that the Forty-Eighters were called to "both write and make history" (Zub 1974, 259). Even so, he displayed the capacity to distance himself from the political passions of the moment and to temper his abolitionist zeal by adopting a critical distance towards his research topic. Seen from an alternate perspective, it could be argued that Kogălniceanu's study is proof that, however antithetical it may be to positivist historical norms, social militancy had the potential to expand historical understanding by driving scholars of abolitionist convictions to reevaluate existing historical discourse or established knowledge by seeking new documentary evidence in support of their innovative and radical claims.

Kogălniceanu's treatment of slavery in classical antiquity serves to illustrate this last point. Relying primarily on ancient sources, ranging from Aristotle's Politics to Xenophon's Ways and Means, and taking certain nineteenth-century studies as points of reference, particularly Auguste Boeckh's Economie politique des athéniens and Charles Comte's Traité de législation..., Kogălniceanu argued that slavery represented nothing more than an artificial "social convention" born out of violence and greed, institutionalized by ruling elites, and kept alive primarily by economic interests. In putting forward this argument, routinely accepted nowadays but still controversial in those times, he intended not only to challenge Aristotle's so-called theory of "natural slavery" (Politics 1.5, 1254b, 16-39), used and abused in certain pro-slavery pamphlets and articles, but also to provide an alternative (and ultimately more compelling) reading of the ancient sources. Kogălniceanu's interpretation of slavery encouraged readers to reexamine, from a critical perspective, the evolution of Ancient Greece and Rome as proper "slave-based societies", whose prosperity depended to a large extent on the exploitation of slave labour:

Slavery is as old as the world itself, claim its defenders; many scholars say that as well, driven by a hollow erudition. Slavery is ancient indeed, but not as old as the world; it began as soon as the craft of production developed itself enough to provide man with more than he actually 
needed for his survival. As long as this surplus did not appear, slavery was not possible, because there was no interest in owning slaves... Therefore, spoliation and theft lie at the origin of slavery (Kogălniceanu 1976, 484).

Roma slavery in the Romanian principalities represented a more topical case study that unavoidably raised a number of additional challenges due to the ambiguity that shrouded its distant origins, its perplexing persistence until modern times, and the increasing passions it aroused among local elites. It is unfortunate that the last section of Kogălniceanu's study, in which he likely intended to tackle some of these issues, was suppressed by censorship and has yet to be recovered from his original manuscripts. We may infer, based on the published two chapters of the study, that Kogălniceanu used a similar mixture of persuasive anti-slavery rhetoric and well-documented historical arguments to expose the unnatural and unjust nature of this "black stain in the social history of every nation, which, in spite of the enlightenment of our age, still exists among nations that call themselves Christian” (Kogălniceanu 1976, 483). A few remarks on Romani slavery did manage to pass the rigours of censorship, probably because they appeared as "matter-of-fact accounts." First, there was the mention of some emancipated Roma (possibly former Crown or monastery slaves) who accepted to wear once again the chains of servitude because they were in dire need and "did not truly know the price [read value] of freedom" (Kogălniceanu 1976, 484). Second, there was a passing reference to the fact that local Orthodox monasteries "did not cease to own slaves until the year 1844" (ibid., 491). And third, Kogălniceanu described the important role played by local slaves in nursing and looking after their boyar masters' children, a questionable practice according to him, and one that was also documented in the aristocratic families of ancient Rome (ibid., 488).

Attempts to reconstruct the line of argumentation from the censored part of Kogălniceanu's study would take the text exegesis into the realm of speculation, and thus confer a tentative nature to all arguments made from this point forward. Such efforts should naturally depart from analysis of Kogălniceanu's pre1853 writings on the topic of Roma slavery, particularly his Esquisse sur l'histoire... from 1837, and the abolitionist articles published in the Moldavian journal Steaua Dunării (Star of the Danube) from 1855 to 1856. The Manumission of Gypsies..., the discourse he delivered at the Romanian Academy in 1891, needs to be carefully reviewed in order to steer clear from the pitfalls of anachronistic or teleological views. In his senior years, Kogălniceanu developed a tendency to recount his life trajectory as a relentless struggle towards the modernization and unity of the Romanian principalities, going as far as to publicly boast that he had never strayed from his principles in his political career (Zub 1971, 77). This tendency to project a certain linearity and coherence over his long career, which discretely manifests itself in his discourse from 1891, does not necessarily detract from its historical value.

Without losing sight of these potential limitations, there appears to be a common tendency in the abovementioned studies for Kogălniceanu to describe Roma slavery as an intriguing historical and social "puzzle." The historical aspect derived from the fact that existing historical records made obscure mentions about the origins of Roma and how their distant Indian roots could be retraced primarily based on linguistic and ethnographic sources (Kogălniceanu 1837, 3). Kogălniceanu claimed that wars of conquests and spoliation lay at the roots of most "slave systems," including in Moldova, but could not further elaborate on this topic. The social dimension of the "puzzle" was related to the long-term coexistence of this archaic form of bondage (robia), which defined the social existence of local Roma 
for many centuries, with vecinia and rumânia, the local variants of peasant serfdom in Moldova and Wallachia. Kogălniceanu pointed out the perplexing fact that Romani slaves and peasant serfs had, in many cases, the same masters (local monasteries or boyars) and were subjected to a similarly abusive treatment, yet the formal distinction between these two forms of bondage remained clear in the Moldavian codes of law, as slaves were bound to the person of their master and serfs were tied to their master's lands (Kogălniceanu 1976, 492). His analysis attempted to go beyond the normative aspects of slavery and serfdom, as they were defined in the local codes of law, and explore new aspects of social history based on archival materials he had recently identified in the local archives and/or published in historical magazines such as Arhiva românească (Romanian archive) (Kogălniceanu 1860, 94-9). The chrysobull or the official resolution of the Moldavian Assembly of Estates of April 1749 was arguably the most relevant because it listed three criteria - family ties, nature of bondage, and type of work - that differentiated Moldavian serfs from Romani slaves in the early eighteenth century. This document, cited in Kogălniceanu's study, offers a glimpse of the control that boyar masters had over their Romani slaves, as the latter could be bought and sold together or separate from family members, moved from one estate to another, and compelled to perform whatever tasks their masters assigned them (Kogălniceanu 1976, 498).

Despite their dissimilarities, Kogălniceanu described Romani slavery and peasant serfdom as "social aberrations," incompatible with modern institutions in the principalities and thus in urgent need of being abolished (ibid., 484). It is plausible that Ochire istorică asupra sclăviei further developed this line of argumentation, as the analysis was moving closer to the present-day situation, likely provoking the illfated intervention of the Moldavian censorship bureau.

\section{Conclusion}

The findings about Kogălniceanu's study of slavery that were briefly discussed in this article prove that he had a firm command of both anti-slavery rhetoric and historical scholarship, and through his work as an abolitionist and a researcher attacked the institution of slavery in the Romanian principalities. As the study of his intellectual formation in France and Prussia, and his involvement in the political debates of his time suggests, it is not always possible to draw a clear line between these two facets of Kogălniceanu's activity without taking away from his grandiloquence or the militancy of his text. In fact, historical scholarship and militant rhetoric represent two prominent features of the Romantic forms of social criticism developed by the Romanian Forty-Eighters in response to the social inequalities of their time. Such an attempt would be even further complicated by the unfortunate omissions in Kogălniceanu's study, a testimony across the ages of the rigors endured and the losses suffered by militant scholars, including Kogălniceanu, in their relentless struggle to expose what was unjust or lacking in their society, and what corrective measures needed to be adopted.

The specific details of Kogălniceanu's pioneering analysis of Romani slavery require further research and clarification, as the lingering questions about the missing last section continue to cast a shadow of doubt over its actual informational value. Nonetheless, one cannot simply deny the importance of Kogălniceanu's innovative perspective on the institution of Romani slavery, with its holistic approach, strong command of primary sources, and propensity towards relevant historical comparisons. 


\section{References}

\section{Primary sources}

Aristotle. 1995. Politics. Translated by Ernest Barker. Revised with an Introduction and Notes by R. F. Stalley. Oxford/New York: Oxford University Press.

Bălcescu, Nicolae. 1974. Opere, Vol. 1 (Scrieri istorice, politice și economice, 1844-1847) [Complete Works, Vol. 1, Social, Political and Economic Writings, 1844-1847]. Edited by Gheorghe and Elena Zane. București: Editura Academiei Republicii Socialiste România.

Beecher Stowe, Harriet. 1853. Coliba lui Moșu’ Toma sau Vieața Negrilor în sudul Statelor-Unite din America, 2 Vols. Translated from French by Theodor Codrescu. With a Brief Historical Survey by Mihail Kogălniceanu. Iași: Tipografia Buciumul Român. Originally published in English as Uncle Tom’s Cabin or, Life Among the Lowly (Boston and Cleveland, 1852).

Bodea, Cornelia, ed. 1982. 1848 la români: O istorie în date și mărturii [The Romanians and the year 1848: A history in dates and testimonies], Vol. 1. București: Editura Științifică.

Kogălniceanu, Mihail. 1837. Esquisse sur l'histoire, les mours et la langue des cigains, connus en France sous le nom de Bohémiens, suivie d’un recueil de sept cents mots cigains. Berlin: Librairie de B. Behr.

_. 1855. "Iaşii, 29 noemvri” (Iași, 29 November). Steaua Dunării 1, No. 26 (29 November): 101-3.

. 1860. "Act pentru Desrobirea vecinilor în Moldova. 1749" ["Resolution concerning the emancipation of serfs in Moldova. 1749”]. Arhiva românească 1, 2nd ed.: 94-9.

—. 1892. "Desrobirea Țiganilor. Oborîrea pronomiilorŭ și privilegiilorŭ de nascere și de castă. Emanciparea țăranilor” [The manumission of Gypsies: The abolition of birth and cast privileges. The emancipation of peasants]. Analele Academiei Române. Partea administrativă și dezbaterile XIII (1890-1891), 2nd series: 255-300.

1974. Opere, Vol. I (Beletristica, studii literare, culturale și sociale) [Selected works, Vol. 1. Works of fiction, literary, cultural and social studies]. Edited by Dan Simionescu. București: Editura Academiei Republicii Socialiste România.

1976. Opere, Vol. II (Studii istorice) [Selected Works, Vol. II. Historical Studies]. Edited by Alexandru Zub. București: Editura Academiei Republicii Socialiste România.

Palade, Ion, ed. 1907. Codul Caragea reprodus după manuscrisul original românesc [Prince Caragea’s code, copied after the original Romanian manuscript]. București: Editura Librăriei Leon Alcalay.

\section{Secondary sources}

Achim, Venera. 2006. “Documente inedite despre Mihail Kogălniceanu şi rolul său în dezrobirea ţiganilor” [New documents concerning Mihail Kogălniceanu and his role in the manumission of Gypsy slaves]. In Naţiunea română: Idealuri şi realități istorice. Acad. Cornelia Bodea la 90 de ani, edited by Alexandru Zub, Venera Achim, and Nagy Pienaru, 467-74. București: Editura Academiei.

2009. Emanciparea ţiganilor şi programul legislativ al guvernului provizoriu din 1848 (The emancipation of Gypsy slaves and the programme of legal reforms adopted by the provisional government of 1848). Revista istorică 20 (1-2): 63-72. 
Achim, Viorel. 2004. The Roma in Romanian History. Translated by Richard Davies. Budapest and New York: Central European Press. Originally published in Romanian as Țiganii în istoria României. București: Editura Enciclopedică, 1998.

Boia, Lucian. 2011. Istorie și mit în conștiința românească [History and myth in Romanian consciousness], 3rd Ed. București: Editura Humanitas.

Boicu, Leonid. 1973. Adevărul despre un destin politic: Domnitorul Gr. Al. Ghica (1849-1856) [The truth about a political destiny: Prince Grigore Al. Ghica, 1849-1856]. Iași: Junimea.

Cartojan, Nicolae. 1925. Mihail Kogălniceanu la Paris în 1846 [Mihail Kogălniceanu in Paris in 1846]. Craiova: Flamura.

Ciurea, Dimitrie. 2012. Moldova sub domnia lui M. Sturza: Dela convenția dela Petersburg (1834) la convenția dela Balta-Liman (1849) [Moldova under the reign of M. Sturdza: From the Petersburg Convention of 1834 to the Balta-Liman Convention of 1849]. Edited by Stela Cheptea and Gheorghe Buzatu, with a forward by Alexandru Zub. Iași: TipoMoldova.

Cristian, Vasile. 1996. Istoriografia pașoptistă (The Romanian Romantic historiography of 1848). Iași: Editura Universității Alexandru Ioan Cuza.

Dassow Walls, Laura. 2009. The Passage to Cosmos: Alexander von Humboldt and the Shaping of America. Chicago and London: University of Chicago Press.

Ghenghea, Mircea-Cristian. 2013. "Un eveniment editorial în Principatul Moldovei în anul 1853: Coliba lui Moșu' Toma" [An editorial event in the Principality of Moldova in 1853: Uncle Tom' Cabin]. Studii şi materiale de istorie modernă 26: 86-92.

Hitchins, Keith. 2014. A Concise History of Romania. Cambridge: Cambridge University Press.

Ionescu, Virgil I. 1963. Mihail Kogălniceanu: Contribuții la cunoașterea vieții, activității și concepțiilor sale [Mihail Kogălniceanu: A contribution to the study of his life, Activities and fundamental beliefs]. București: Editura Științifică.

_ 1979. Opera lui Mihail Kogălniceanu sub raportul faptei și gândirii social-economice [Mihail Kogălniceanu’s work in light of his actions and social-economic thinking]. Craiova: Editura Scrisul Românesc.

Iordachi, Constantin. 2019. Liberalism, Constitutional Nationalism, and Minorities: The Making of Romanian Citizenship, c. 1750-1918. Leiden and Boston: Brill.

Lupaș, Ioan. 1937. "Leopold Ranke si Mihail Kogălniceanu” [Leopold Ranke and Mihail Kogălniceanu]. Academia Română, Memoriile Secțiunii Istorice 18, 3rd Series: 311-28.

Pintilie, Serinela. 2006-2007. "Mihail Kogălniceanu și intelectualii din Prusia" [Mihail Kogălniceanu and Prussian scholars]. Anuarul Institutului de Istorie "A. D. Xenopol" 43-44: 633-648.

Potra, George. 1939. Contribuțiuni la istoricul țiganilor din România [Contributions to the history of the Gypsies in Romania]. București: Fundația Regelui Carol I.

Răduțiu, Aurel. 1973. Incursiuni în istoriografia vieții sociale [Explorations in the historiography of social life]. Cluj: Editura Dacia.

Simionescu, Dan, 1955. “Un studiu necunoscut de istorie socială al lui Mihail Kogălniceanu, gâtuit de cenzură” [An unknown study of social history written by Mihail Kogălniceanu, suppressed by censorship]. Studii, Revistă de Istorie 8 (5-6): 137-46.

Tomi, Raluca, 2009. “Aboliționismul românesc la 1848: Influențe, trăsături” [Romanian abolitionism in 1848: Influences and characteristics]. Revista istorică 20 (1-2): 47-61. 
Zub, Alexandru. 1971. Mihail Kogălniceanu, 1817-1891: Biobibliografie [Mihail Kogălniceanu, 1817-1891: His life and works]. București: Editura Enciclopedică Română and Editura militară.

. 1973. “M. Kogălniceanu și Gr. A. Ghica (note pe marginea unor manuscrise inedite)” [M. Kogălniceanu and Gr. A. Ghica, Notes concerning some unpublished documents]. Revista Arhivelor 35 (4): 609-30.

1974. Mihail Kogălniceanu istoric [Mihail Kogălniceanu as a historian]. Iași: Junimea.

2005. Mihail Kogălniceanu: Un arhitect al României moderne [Mihail Kogălniceanu: One of the founding figures of modern Romania]. Iași: Institutul European. 